\title{
EXTENSION OF EMPLOYEE CONTRACTS BASED ON PERFORMANCE APPRAISAL AT BNN LAMPUNG PROVINCE USING THE VIKOR METHOD
}

\author{
Cindy Naulina Cahyani ${ }^{1}$; Rani Irma Handayani ${ }^{2 *}$; Normah $^{3}$ \\ Information Systems \\ STMIK Nusa Mandiri, Jakarta, Indonesia \\ www.nusamandiri.ac.id \\ cindynaulina@gmail.com ${ }^{1}$; rani.rih@nusamandiri.ac.id ${ }^{2 *}$; normah.nor@nusamandiri.ac.id ${ }^{3}$ \\ $\left({ }^{*}\right)$ Corresponding Author
}

\begin{abstract}
The process of an employee contract extension at BNNP Lampung was previously carried out when the contract employee had completed his work contract for one year and during the work process. This results in good work progress and is still needed by the Lampung BNNP, so a report will be made on which employees will be extended their work contract after which the report is given to the Head of the Lampung BNNP to approve the employee contract extension decision letter, for that an appropriate decision support system is needed and efficient so that it can assist in making decisions on employee contract extensions. This decision support system is made based on performance appraisal by predetermined criteria, namely attitude, workability, attendance, period of employment, and age, if all these criteria are met, the work contract will be extended. This decision support system is created using the Vikor method to obtain the best ranking results taken from alternatives on each criterion that is close to the ideal solution. To produce the best solution in the decision support system for employee contract extension based on the performance appraisal at BNN Lampung Province. The calculation of the Vikor method in this study produces the smallest $Q$ value as the first rank with a value of 0.025 in alternative 6 and the largest $Q$ value as the last rank with a value of 0.8333 in alternative 8 .
\end{abstract}

Keywords: Decision Support System, Employee Contract, Vikor Method.

Abstrak-Proses alur perpanjangan kontrak karyawan pada BNNP Lampung sebelumnya dilakukan ketika karyawan kontrak tersebut telah menyelesaikan kontrak kerjanya selama satu tahun dan selama proses kerja tersebut menghasilkan progres kerja yang baik dan masih dibutuhkan oleh BNNP Lampung maka akan dibuatkan laporan karyawan mana saja yang akan diperpanjangan kontrak kerjanya setelah itu laporan tersebut diberikan kepada Kepala BNNP Lampung untuk menyetujui surat keputusan perpanjangan kontrak karyawan, untuk itu diperlukan sistem pendukung keputusan yang tepat dan efisien sehingga dapat membantu dalam pengambilan keputusan perpanjangan kontrak karyawan. Sistem pendukung keputusan ini dibuat berdasarkan penilaian kinerja yang sesuai dengan kriteria yang telah ditetapkan yaitu attitude, kemampuan bekerja, absensi, masa kerja, dan umur, jika semua kriteria tersebut terpenuhi maka kontrak kerja akan diperpanjang. Sistem pendukung keputusan ini dibuat dengan menggunakan metode vikor bertujuan untuk memperoleh hasil perangkingan terbaik yang diambil dari alternatif pada setiap kriteria yang mendekati solusi ideal. Sehingga menghasilkan solusi terbaik dalam sistem pendukung keputusan perpanjangan kontrak karyawan berdasarkan penilaian kinerja pada BNN Provinsi lampung. Perhitungan metode vikor pada penelitian ini menghasilkan nilai $Q$ terkecil sebagai peringkat pertama dengan nilai 0,025 pada alternatif 6 dan nilai $Q$ terbesar sebagai peringkat terakhir dengan nilai 0,8333 pada alternatif 8 .

Kata Kunci: Sistem Pendukung Keputusan, Kontrak Karyawan, Metode Vikor.

\section{INTRODUCTION}

Human resource is one of the parts that must be owned for the sustainability of a company (Meidawati, 2015). The human resources in question are employees who work for the company. Employees play a very important role in achieving the operational success of a company, to achieve this success the company must have employees who are competent according to their areas of expertise. For this reason, the company must select prospective employees according to the criteria set by the company and be carried out appropriately and efficiently.

Contract employees are employees who work in a company with a predetermined working period by the work contract agreement that has been mutually agreed upon. If the contract employee produces good work progress during the work contract and meets several criteria in the performance appraisal that is a consideration for the employee work contract extension. By conducting a performance appraisal of employees, 
it will provide an overview of the company as to what employee behavior is related to work as well as information regarding compensation, training and development, employee promotion, and others (Evita et al., 2017).

The National Narcotics Agency of Lampung Province has been carrying out the decision-making process by selecting one by one the performance data files of contract employees during the working period, if the results of one year of work produce good work and as long as the employee is still needed to work at the Lampung Province BNN which employee data will be extended to work contracts for one year by the Personnel Development Officer chaired by the Head of General Affairs after which the report is submitted to the Head of the Lampung Province BNN to approve the employee contract extension decision letter so that in this case it takes a longer time to make decisions on employee contract renewals. For that we need an appropriate and fast system, a decision support system is needed as a solution to the existing problems. The decision support system is known as the Decision Support System (DSS). As the name implies, the purpose of this system is to support decision making in choosing decision alternatives which are the results of processing information obtained using decision-making models, and to solve problems that are of nature. structured, semistructured, and unstructured (Ainun, 2019).

Based on the existing problems, the authors provide a solution to create a decision support system for an employee contract extension at BNN Lampung Province using the VIKOR method to simplify and speed up the decision-making process (Thabrani et al., 2019). With this decision support system, it is hoped that it can be the right choice for making decisions on employee contract extensions.

In previous research conducted by Wina Yusnaeni, Marlina (2019) in assessing employee performance through the AHP and VIKOR methods with several criteria including attendance, sales results, attitude, length of work, educational background. Then a ranking is obtained using the VIKOR method (Yusnaeni \& Marlina, 2019). Subsequent research on decision support systems using the VIKOR method (Vise Kriterijumska Optimizajica I Kompromisno Resenje) for the election of the best branch head. VIKOR is a multicriteria optimization and compromise solution (multi-criteria optimization and compromise solutions) used in multi-criteria decision-making problems (Hutapea et al., 2018; Shumaiza et al., 2019). Subsequent research on the application of the AHP and VIKOR methods in selecting outstanding employees. Making improper decisions will result in employees being elected sometimes not by the real facts (Wijaya \& Mesran, 2019).
Subsequent research applies the VIKOR method in selecting experts at the Ministry of Communication and Information, the VIKOR method focuses on ranking between alternatives and interrelated criteria (Harahap et al., 2018).

Further research regarding the selection of the best pharmacist by applying the VIKOR method, the company can develop properly, of course, is influenced by the quality of its employees (Kusuma \& Ginting, 2020). Subsequent research is the application of the Vikor method in decision making for candidate recipients of the Bidikmisi scholarship with academic and achievement criteria, economic ability, commitment, school quality order, school representation, and regional origin (Suniantara \& Suwardika, 2018). Further research in improving the quality of human resources can be carried out by organizing high school level quiz, implementing decision support in the selection of quiz candidate participants using the VIKOR method (Sutrikanti et al., 2018).

The selection of outstanding school principals is carried out to improve quality and management in school education by implementing the VIKOR method, which is expected to make it easier to make decisions (Wulan et al., 2018). Subsequent research was carried out to determine the feasibility of providing life insurance to fishermen using the VIKOR method by determining the level of importance of each criterion (Nasution \& Ulfa, 2020). Subsequent research applies the VIKOR method in the selection of bonus receipts for Indihome salesmen with a selection-ranking profit decision support system (Primadasa \& Juliansa, 2019). Decision support systems are an effective way to test the eligibility of new employees by applying the VIKOR and MOORA methods (Sarumaha et al., 2018). The determination of outstanding employees can be calculated based on the calculation of the weight of the respective criteria by applying the VIKOR method (Trisnani et al., 2018).

This study aims to facilitate decision-making in determining the extension of existing employee contracts at BNNP Lampung to be more accurate and fast.

\section{MATERIALS AND METHODS}

\section{A. Research Stages}

1. Problems

The initial stage was carried out by the author by making observations to find out and find problems that exist in BNNP Lampung. 


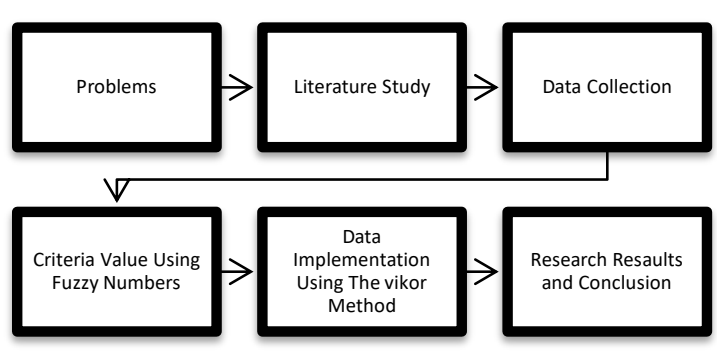

Source: (Cahyani, 2020)

Figure 1. Research Stages

\section{Literature Study}

At the literature study stage, the writer carried out literacy with previous research that had been carried out related to employee contract renewal through journals, e-books, and others.

\section{Data Collection}

The collection stage is carried out by collecting all the information needed to get results and solutions to the problems in this study. At the data collection stage, interviews were conducted with the Head of the Administration Subdivision regarding the employee contract extension system in BNNP Lampung.

\section{Criteria Value Using Fuzzy Numbers}

The process at this stage is to assign values to each employee contract extension criteria using fuzzy numbers.

5. Data Implementation Using the Vikor Method

At this stage, data processing is carried out using the Vikor method, the first stage is making alternatives and criteria into the form of a decision matrix, the second stage, by determining the criteria weights, the third stage is creating a normalization matrix, then it is done by multiplying the criteria weights The next step is to calculate the $S$ and $R$ values, after that calculating the Vikor index value, the last step to do is to rank the alternatives with the smallest $Q$ value as the best sample.

6. Research Result and Conclusion

At this stage, the authors take the results and conclusions based on the results obtained from the initial stages of problem identification to data implementation using the Vikor method of decision support systems for employee contract extension decisions at BNNP Lampung.

\section{B. Data Sources}

used in this study are secondary data and primary data, secondary data, namely data on contract employees, sourced from BNNP Lampung.
Primary data is conducting literature studies obtained from journals, e-books, and others related to the Decision Support System for Determining Employee Contract Extensions Based on Performance Appraisal at BNNP Lampung Using the Vikor Method.

\section{Data Analysis}

In the data analysis method, the process stages are carried out in determining the extension of the employment contract at BNNP Lampung as follows:

1. Determine and create a criteria table

2. Create alternative tables and match the criteria table

3. Values to the weight of criteria

4. Assign value the beginning of the criteria for attitude, attendance, workability, years of service, and age using fuzzy numbers.

The data calculation uses the Vikor method to rank each alternative for which the work contract extension will be extended.

The steps for solving problems using the VIKOR method (Ainun, 2019) are as follows:

1. Normalizing the Matrix

$R_{i j}=\left(\frac{X j^{+}-X i j}{X j^{+}-X j^{-}}\right)$

\section{Description:}

$X \mathrm{ij}=$ Sample data value $l i$ criteria $j$

$(\mathrm{i}=\mathrm{A}, \mathrm{B}, \mathrm{C}, \mathrm{D}, \mathrm{E})$

$(\mathrm{j}=5$ criteria)

$\mathrm{X}_{\mathrm{j}}^{+}=$the best score in one criteria

$\mathrm{X}_{\mathrm{j}}=$ the worst score in one criteria

2. Calculating the value of $S$ and $R$

$\mathrm{Si}=\sum_{j=1}^{n} w j \times(R i j)$

Description:

$\mathrm{Wj}=$ The weight of criterion

value of $S$ is obtained from the sum of the multiplication results of the criteria weights with the data in each sample.

$\mathrm{Ri}=\operatorname{Max} \mathrm{j}[\mathrm{Wj} \times \mathrm{Rij}]$

value of $R$ is the largest value from the multiplication of the criterion weight with the normalized data from each sample.

3. Calculating the Vikor Index

$$
\begin{aligned}
& Q=\left[\frac{S_{i}-S^{-}}{S^{+}-S^{-}}\right] \times V+\left[\frac{R^{-}-R^{-}}{R^{+}-R^{-}}\right] \times(1-V) \\
& \text { Description: } \mathrm{S}^{-}=\operatorname{Min} \mathrm{S}_{\mathrm{i}} \\
& \mathrm{S}^{+}=\operatorname{Max} \mathrm{S}_{\mathrm{i}} \\
& \mathrm{R}^{-}=\operatorname{Min} \mathrm{R}_{\mathrm{i}} \\
& \mathrm{R}^{+}=\operatorname{Max} \mathrm{R}_{\mathrm{i}}
\end{aligned}
$$

Sample with smallest $Q$ Value is the best sample. 


\section{Data Criteria and Weights}

In the process of determining employee contract extensions, criteria are needed as an initial stage before proceeding to the data calculation stage in this research. The head of the Subdivision of Administration as one of the experts in decision making at BNNP Lampung gives the scoring of the criteria weight. The criteria and weights can be seen in Table 1.

Table 1. Criteria

\begin{tabular}{cl}
\hline Criteria & \multicolumn{1}{c}{ Description } \\
\hline C1 & Attitude \\
C2 & WorkAbility \\
\hline C3 & Attendance \\
\hline C4 & Age \\
\hline C5 & Period of Employment \\
\hline
\end{tabular}

Source: (Cahyani, 2020)
The results of scoring for the weighting of the criteria can be seen in table 2 .

Table 2. Criteria Weights

\begin{tabular}{cclc}
\hline No & Criteria & \multicolumn{1}{c}{ Description } & $\begin{array}{c}\text { Weight } \\
\text { (\%) }\end{array}$ \\
\hline 1 & C1 & Attitude & 30 \\
\hline 2 & C2 & WorkAbility & 25 \\
\hline 3 & C3 & Attendance & 20 \\
\hline 4 & C4 & Age & 15 \\
\hline 5 & C5 & Period Of Employment & 10 \\
\hline
\end{tabular}

Source: (BNN Lampung, 2020)

Data on the Lampung BNNP Honorary Employees used in this research, which can be seen in table 3 .

Table 3. Data of Honorary BNNP Lampung

\begin{tabular}{|c|c|c|c|c|c|c|}
\hline \multirow[b]{2}{*}{ No } & \\
\hline & Name & Attitude & WorkAbility & Attendance & Age & $\begin{array}{c}\text { Period of } \\
\text { Employment }\end{array}$ \\
\hline 1 & Ahmad Subari & Good & Very Good & 80 & 43 & $>10$ \\
\hline 2 & Doni Saputra & Very Good & Good & 77 & 34 & $>10$ \\
\hline 3 & Eko Budiyono & Good & Good & 93 & 36 & $>10$ \\
\hline 4 & Melinawati & Good & Good & 74 & 36 & $>10$ \\
\hline 5 & Erik Firmasyah & Very Good & Very Good & 78 & 35 & $>10$ \\
\hline 6 & Eko Kusdarwanto & Good & Good & 89 & 31 & $>10$ \\
\hline 7 & Junaidi & Very Good & Enough & 81 & 41 & 8 \\
\hline 8 & R. M. Andi Zohari & Good & Enough & 76 & 56 & 9 \\
\hline 9 & Sumardi & Enough & Enough & 88 & 40 & $>10$ \\
\hline 10 & Ernani & Very Good & Very Good & 79 & 47 & $>10$ \\
\hline 11 & Desi Komalasari & Good & Good & 91 & 40 & $>10$ \\
\hline 12 & Nanih Saptarina & Enough & Very Good & 87 & 38 & 10 \\
\hline 13 & Ayef Priasep & Enough & Very Good & 73 & 34 & $>10$ \\
\hline 14 & Samuel Pengindoan Napitupulu & Very Good & Good & 85 & 33 & 8 \\
\hline 15 & Etika Mutia Sari & Good & Very Good & 89 & 34 & $>10$ \\
\hline 16 & Julianto & Enough & Good & 96 & 42 & $>10$ \\
\hline 17 & Dedi Supriyadi & Very Good & Good & 87 & 35 & 10 \\
\hline 18 & Octa Marselina. S.SI & Good & Good & 90 & 31 & 10 \\
\hline 19 & Halley Putra Perdana & Good & Good & 84 & 34 & 8 \\
\hline 20 & Andi Swastani & Good & Enough & 90 & 33 & 8 \\
\hline \multicolumn{7}{|c|}{ Source: (BNN Lampung, 2020) } \\
\hline \multirow{3}{*}{\multicolumn{3}{|c|}{$\begin{array}{l}\text { E. Assigning Initial Values to Criteria Using Fuzzy } \\
\text { Numbers }\end{array}$}} & Attitude & \multicolumn{2}{|c|}{ Fuzzy Number } & Value \\
\hline & & & Very Good & \multicolumn{2}{|c|}{ Very Good } & 30 \\
\hline & & & Good & \multicolumn{2}{|l|}{ Good } & 20 \\
\hline \multicolumn{3}{|c|}{$\begin{array}{l}\text { This initial value assignment consists of three fuzzy } \\
\text { numbers by the level of importance, which is in }\end{array}$} & Enough & \multicolumn{2}{|l|}{ Enough } & 10 \\
\hline
\end{tabular}
numbers by the level of importance, which is in table 4 below.

Table 4. Fuzzy Number Value

\begin{tabular}{ll}
\hline Fuzzy Numbers & Value \\
\hline Very Good (SB) & 30 \\
\hline Good (B) & 20 \\
\hline Enough (C) & 10 \\
\hline
\end{tabular}

Source: (Cahyani, 2020)

The results of giving fuzzy number values on attitude criteria can be seen in table 5 .

Table 5. Numbers value Fuzzy on Attitude Criteria
Source: (Cahyani, 2020)

Values for fuzzy numbers on the criteria of workability can be seen in table 6 .

Table 6. Numbers Value Fuzzy on Work Ability Criteria

\begin{tabular}{lll}
\hline WorkAbility & Fuzzy Number & Value \\
\hline Very Good & Very Good & 30 \\
\hline Good & Good & 20 \\
\hline Enough & Enough & 10 \\
\hline
\end{tabular}

Source: (Cahyani, 2020) 
The results of giving fuzzy number values on the Attendance criteria can be seen in Table 7.

Table 7. Numbers Value Fuzzy on Attendance Criteria

\begin{tabular}{lll}
\hline Attendance & Fuzzy Number & Value \\
\hline $90-100$ & Very Good & 30 \\
\hline $80-89$ & Good & 20 \\
\hline $70-79$ & Enough & 10 \\
\hline
\end{tabular}

Source: (Cahyani, 2020)

The results of giving fuzzy number values for age criteria can be seen in table 8 .

Table 8. Numbers Value Fuzzy on Age Criteria

\begin{tabular}{lll}
\hline Age & Fuzzy Number & Value \\
\hline $21-26$ years & Very Good & 30 \\
\hline $27-32$ years & Good & 20 \\
\hline$>33$ years & Enough & 10 \\
\hline Source: $($ Cahyani, 2020) & &
\end{tabular}

Source: (Cahyani, 2020)

The results of assigning fuzzy number values for a period of employment criteria can be seen in table 9 .

Table 9. Numbers Value Fuzzy on Period of Employment Criteria

\begin{tabular}{|c|c|c|}
\hline $\begin{array}{c}\text { Period of } \\
\text { Employment }\end{array}$ & Fuzzy Number & Value \\
\hline$>10$ years & Very Good & 30 \\
\hline $5-10$ years & Good & 20 \\
\hline 1 - 4 years & Enough & 10 \\
\hline
\end{tabular}

Source: (Cahyani, 2020)

\section{RESULTS AND DISCUSSION}

The results of giving the initial value of fuzzy numbers on each criterion that has been matched with the contract employee data at BNNP Lampung can be seen in table 10 .

Table 10. Compatibility Rating for Alternatives

\begin{tabular}{cccccc}
\hline Alternative & \multicolumn{5}{c}{ Criteria } \\
& C1 & C2 & C3 & C4 & C5 \\
\hline A1 & 20 & 30 & 20 & 10 & 30 \\
\hline A2 & 30 & 20 & 10 & 10 & 30 \\
\hline A3 & 20 & 20 & 30 & 10 & 30 \\
\hline A4 & 20 & 20 & 10 & 10 & 30 \\
\hline A5 & 30 & 30 & 10 & 10 & 30 \\
\hline A6 & 20 & 20 & 20 & 20 & 30 \\
\hline A7 & 30 & 10 & 20 & 10 & 20 \\
\hline A8 & 20 & 10 & 10 & 10 & 20 \\
\hline A9 & 10 & 20 & 20 & 10 & 30 \\
\hline A10 & 30 & 30 & 10 & 10 & 30 \\
\hline A11 & 20 & 20 & 30 & 10 & 30 \\
\hline A12 & 10 & 30 & 20 & 10 & 20 \\
\hline A13 & 20 & 30 & 10 & 10 & 30 \\
\hline A14 & 30 & 20 & 20 & 10 & 20 \\
\hline A15 & 20 & 30 & 20 & 10 & 30 \\
\hline A16 & 10 & 20 & 30 & 10 & 30 \\
\hline
\end{tabular}

\begin{tabular}{cccccc}
\hline Alternative & \multicolumn{5}{c}{ Criteria } \\
& C1 & C2 & C3 & C4 & C5 \\
\hline A17 & 30 & 20 & 20 & 10 & 20 \\
\hline A18 & 20 & 20 & 30 & 20 & 20 \\
\hline A19 & 20 & 20 & 20 & 10 & 20 \\
\hline A20 & 20 & 10 & 30 & 10 & 20 \\
\hline
\end{tabular}

Source: (Cahyani, 2020)

\section{A. Matrix Normalization Data}

The suitability rating data will be continued by creating a matrix normalization data from each criterion obtained from the calculation with the matrix normalization formula. The following is the calculation of normalization data for each criterion.

Data Normalization For C1

$\mathrm{R}(\mathrm{A} 1), \mathrm{C} 1=\frac{(30-20)}{(30-10)}=\frac{10}{20}=0,5$

Data Normalization For C2

$\mathrm{R}(\mathrm{A} 1), \mathrm{C} 2=\frac{(30-30)}{(30-10)}=\frac{0}{20}=0$

Data Normalization For C3

$\mathrm{R}(\mathrm{A} 1), \mathrm{C} 3=\frac{(30-20)}{(30-10)}=\frac{10}{20}=0,5$

Data Normalization for $\mathrm{C} 4$

$\mathrm{R}(\mathrm{A} 1), \mathrm{C} 4=\frac{(20-10)}{(20-10)}=\frac{10}{10}=1$

Data Normalization For C5

$\mathrm{R}(\mathrm{A} 1), \mathrm{C} 5=\frac{(30-30)}{(30-20)}=\frac{0}{10}=0$

The calculation results of the matrix normalization data can be seen in Table 11 .

Table 11. Matrix Normalization Data

\begin{tabular}{ccccccc}
\hline \multirow{2}{*}{ No } & Alternative & \multicolumn{5}{c}{ CRITERIA } \\
\cline { 3 - 7 } & & C1 & C2 & C3 & C4 & C5 \\
\hline 1 & A1 & 0,5 & 0 & 0,5 & 1 & 0 \\
\hline 2 & A2 & 0 & 0,5 & 1 & 1 & 0 \\
\hline 3 & A3 & 0,5 & 0,5 & 0 & 1 & 0 \\
\hline 4 & A4 & 0,5 & 0,5 & 1 & 1 & 0 \\
\hline 5 & A5 & 0 & 0 & 1 & 1 & 0 \\
\hline 6 & A6 & 0,5 & 0,5 & 0,5 & 0 & 0 \\
\hline 7 & A7 & 0 & 1 & 0,5 & 1 & 1 \\
\hline 8 & A8 & 0,5 & 1 & 1 & 1 & 1 \\
\hline 9 & A9 & 1 & 0,5 & 0,5 & 1 & 0 \\
\hline 10 & A10 & 0 & 0 & 1 & 1 & 0 \\
\hline 11 & A11 & 0,5 & 0,5 & 0 & 1 & 0 \\
\hline 12 & A12 & 1 & 0 & 0,5 & 1 & 1 \\
\hline 13 & A13 & 0,5 & 0 & 1 & 1 & 0 \\
\hline 14 & A14 & 0 & 0,5 & 0,5 & 1 & 1 \\
\hline 15 & A15 & 0,5 & 0 & 0,5 & 1 & 0 \\
\hline 16 & A16 & 1 & 0,5 & 0 & 1 & 0 \\
\hline 17 & A17 & 0 & 0,5 & 0,5 & 1 & 1 \\
\hline 18 & A18 & 0,5 & 0,5 & 0 & 0 & 1 \\
\hline 19 & A19 & 0,5 & 0,5 & 0,5 & 1 & 1 \\
\hline 20 & A20 & 0,5 & 1 & 0 & 1 & 1 \\
\hline
\end{tabular}

Source: (Cahyani, 2020)

Furthermore, the results of the normalized data will be multiplied by the weight value for each criterion. 
The results of the multiplication can be seen in Table 12.

Table 12. Results of Normalized Data x Weight Value

\begin{tabular}{lllllll}
\hline \multirow{2}{*}{ No } & \multirow{2}{*}{ Alternative } & \multicolumn{5}{c}{ CRITERIA } \\
\cline { 3 - 7 } & & C1 & C2 & C3 & C4 & C5 \\
\hline 1 & A1 & 0,15 & 0 & 0,1 & 0,15 & 0 \\
\hline 2 & A2 & 0 & 0,125 & 0,2 & 0,15 & 0 \\
\hline 3 & A3 & 0,15 & 0,125 & 0 & 0,15 & 0 \\
\hline 4 & A4 & 0,15 & 0,125 & 0,2 & 0,15 & 0 \\
\hline 5 & A5 & 0 & 0 & 0,2 & 0,15 & 0 \\
\hline 6 & A6 & 0,15 & 0,125 & 0,1 & 0 & 0 \\
\hline 7 & A7 & 0 & 0,25 & 0,1 & 0,15 & 0,1 \\
\hline 8 & A8 & 0,15 & 0,25 & 0,2 & 0,15 & 0,1 \\
\hline 9 & A9 & 0,3 & 0,125 & 0,1 & 0,15 & 0 \\
\hline 10 & A10 & 0 & 0 & 0,2 & 0,15 & 0 \\
\hline 11 & A11 & 0,15 & 0,125 & 0 & 0,15 & 0 \\
\hline 12 & A12 & 0,3 & 0 & 0,1 & 0,15 & 0,1 \\
\hline 13 & A13 & 0,15 & 0 & 0,2 & 0,15 & 0 \\
\hline 14 & A14 & 0 & 0,125 & 0,1 & 0,15 & 0,1 \\
\hline 15 & A15 & 0,15 & 0 & 0,1 & 0,15 & 0 \\
\hline 16 & A16 & 0,3 & 0,125 & 0 & 0,15 & 0 \\
\hline 17 & A17 & 0 & 0,125 & 0,1 & 0,15 & 0,1 \\
\hline 18 & A18 & 0,15 & 0,125 & 0 & 0 & 0,1 \\
\hline 19 & A19 & 0,15 & 0,125 & 0,1 & 0,15 & 0,1 \\
\hline 20 & 20 & 0,15 & 0,25 & 0 & 0,15 & 0,1 \\
\hline S0uryyyyyyyyyy & & & & &
\end{tabular}

Source: (Cahyani, 2020)

\section{B. Calculate Values of $\mathbf{S}$ dan $\mathbf{R}$}

Values $S$ values are obtained by adding the results of multiplying data normalization with the weights in each sample. For the R-value, the R-value is obtained from the largest value, the result of multiplying the normalized data with the criterion weight for each sample. The following are the results of the calculation looking for the values of $\mathrm{S}$ and $\mathrm{R}$ which can be seen in table 13 .

Table 13. Results of the Values of S and R

\begin{tabular}{ccc}
\hline Alternative & S Value & R-Value \\
\hline A1 & 0,4 & 0,15 \\
A2 & 0,475 & 0,2 \\
\hline A3 & 0,425 & 0,15 \\
\hline A & 0,625 & 0,2 \\
\hline A5 & 0,35 & 0,2 \\
\hline A6 & 0,375 & 0,15 \\
\hline A7 & 0,6 & 0,25 \\
\hline A8 & 0,85 & 0,25 \\
\hline A9 & 0,675 & 0,3 \\
\hline A10 & 0,35 & 0,2 \\
\hline A11 & 0,425 & 0,15 \\
\hline A12 & 0,65 & 0,3 \\
\hline A13 & 0,5 & 0,2 \\
\hline A15 & 0,475 & 0,15 \\
\hline A16 & 0,4 & 0,15 \\
\hline A17 & 0,575 & 0,3 \\
\hline A18 & 0,475 & 0,15 \\
\hline A19 & 0,375 & 0,15 \\
\hline & 0,625 & 0,15 \\
\hline
\end{tabular}

\begin{tabular}{ccc}
\hline A20 & 0,65 & 0,25 \\
\hline MAX & $\mathbf{0 , 8 5}$ & $\mathbf{0 , 3}$ \\
\hline MIN & $\mathbf{0 , 3 5}$ & $\mathbf{0 , 1 5}$ \\
\hline
\end{tabular}

Source: (Cahyani, 2020)

\section{Calculating the Vikor Index (Q)}

The sample that gets the smallest $Q$ value is called the sample with the best value. The following is the calculation to find the vikor index value $\left(Q_{i}\right)$ :

$$
\begin{aligned}
\mathrm{Q}(\mathrm{A} 1) & =\left[\frac{0,4-0,35}{0,85-0,35}\right] * 0,5+\left[\frac{0,15-0,15}{0,3-0,15}\right] *(1-0,5) \\
& =\left[\frac{0,05}{0,5}\right] * 0,5+\left[\frac{0}{0,15}\right] *(0,5) \\
& =(0,1 * 0,5)+(0 * 0,5) \\
& =0,05
\end{aligned}
$$

following are the results of the Vikor Index (Q) calculation which can be seen in Table 14.

Table 14. Vikor Index

\begin{tabular}{ccc}
\hline Alternative & Q Value & Ranking \\
\hline A6 & 0,025 & 1 \\
\hline A18 & 0,025 & 2 \\
\hline A1 & 0,05 & 3 \\
\hline A3 & 0,05 & 4 \\
\hline A11 & 0,075 & 5 \\
\hline A14 & 0,075 & 6 \\
\hline A17 & 0,125 & 7 \\
\hline A5 & 0,125 & 8 \\
\hline A10 & 0,1666 & 9 \\
\hline A19 & 0,1666 & 10 \\
\hline A2 & 0,275 & 11 \\
\hline A13 & 0,2916 & 12 \\
\hline A4 & 0,3166 & 13 \\
\hline A7 & 0,4416 & 14 \\
\hline A20 & 0,5833 & 15 \\
\hline A16 & 0,6333 & 16 \\
\hline A12 & 0,725 & 17 \\
\hline A9 & 0,8 & 18 \\
\hline A8 & 0,825 & 19 \\
\hline
\end{tabular}

Source: (Cahyani, 2020)

VICOR Index Results From the results of the calculation in the table above, it is obtained that the sample from alternative 6 is obtained the smallest value index value in this study so that it occupies an in the first rank, alternatives 6 and 18 produce the same $Q$ value but when multiplying the matrix normalization data with the criteria weight on C3, alternative 6 produces a value of 0.1 while alternative 18 produces a value of 0 because the value produced by alternative 6 is greater than the alternative. 18 then alternative 6 becomes the first rank in this research.

\section{CONCLUSION}

This Vikor method can assist in the process of selecting and making decisions from several alternatives for an employee contract extension 
based on predetermined criteria, namely: attitude, work ability, attendance, age, and period of employment. This study produces the smallest $\mathrm{Q}$ value with a value of 0.025 in alternative 6 as the first rank, and the largest $Q$ value with a value of 0.8333 in alternative 8 as the last rank. Further research can be developed by applying different methods or by combining methods such as the AHP and VIKOR methods so that the expected results are better. And it can also be developed by applying different criteria and weight values according to the company where the research is conducted, such as adding criteria for education level, work performance to get better results in decision making. This research is intended to be used to facilitate the decision-making process for employee contract extensions at BNNP Lampung to produce the right decision.

\section{REFERENCES}

Ainun, N. (2019). Kontrak Karyawan Berdasarkan Penilaian Kinerja. Sistem Pendukung Keputusan Menentukan Perpanjangan Kontrak Karyawan Berdasarkan Penilaian Kinerja Pada PT. Indomas Makmur Jaya Menggunakan Metode Viktor, 18, 402-410.

BNN Lampung. (2020). Data Karyawan Kontrak. Cahyani, C. N. (2020). Final Research Report: Extension Of Employee Contracts Based On Performance Appraisal At Bnn Lampung Province Using The Vikor Method.

Evita, S. N., Muizu, W. O. Z., \& Atmojo, R. T. W. (2017). Penilaian Kinerja Karyawan Dengan Menggunakan Metode Behaviorally Anchor Rating Scale dan Management By Objectives (Sudi kasus pada PT Qwords Company International). Pekbis Jurnal, 9(1), 18-32. https://pekbis.ejournal.unri.ac.id/index.php/ JPEB/article/view/4051/

Harahap, A., Mesran, M., Ramadhan, S., \& Waruwu, F. T. (2018). Sistem Pendukung Keputusan Pemilihan Tenaga Ahli Pada Dinas Kominfo Kabupaten Deli Serdang Menerapkan Metode Vikor. KOMIK (Konferensi Nasional Teknologi Informasi Dan Komputer), 2(1), 397-402. https://doi.org/10.30865/komik.v2i1.965

Hutapea, B. J., Mesran, M., \& Nurhabibah, S. (2018). Sistem Pendukung Keputusan Pemilihan Kepala Cabang Terbaik Bank Sumut Dengan Menerapkan Metode Vikor. KOMIK (Konferensi Nasional Teknologi Informasi Dan Komputer), 2(1), 185-192. https://doi.org/10.30865/komik.v2i1.926

Kusuma, A., \& Ginting, G. (2020). Sistem Pendukung Keputusan Pemilihan Apoteker Terbaik Pada PT. Kimia Farma (Persero) Tbk
Medan Menerapkan Metode Vikor. Jurnal Sistem Komputer Dan Informatika (JSON), 1(3), 252.

https://doi.org/10.30865/json.v1i3.2163

Meidawati, N. (2015). Penyajian Sumber Daya Manusia dalam Laporan Keuangan (Neraca). 56-62.

Nasution, A., \& Ulfa, K. (2020). Sistem Pendukung Keputusan Kelayakan Pemberian Asuransi Jiwa Untuk Nelayan dengan Menggunakan Metode Vikor (Studi Kasus: Dinas Kelautan dan Perikanan Medan). Jurnal Sistem Komputer Dan Informatika (JSON), 1(3), 220. https://doi.org/10.30865/json.v1i3.2162

Primadasa, Y., \& Juliansa, H. (2019). Penerapan Metode Vikor dalam Seleksi Penerimaan Bonus Pada Salesman Indihome. Digital Zone: Jurnal Teknologi Informasi Dan Komunikasi, 10(1), 33-43. https://doi.org/10.31849/digitalzone.v10i1. 2228

Sarumaha, N. I., Simanungkalit, M., \& Damanik, M. (2018). Sistem Pendukung Keputusan Penerimaan Pegawai Baru Menerapkan Metode VIKOR dan MOORA. Seminar Nasional Sains \& Teknologi Dan Informasi(SENSASI), ISBN: 978-602-52720-0-4, 193-214.

Shumaiza, Akram, M., Al-Kenani, A. N., \& Alcantud, J. C. R. (2019). Group Decision-Making Based on the VIKOR Method with Trapezoidal Bipolar Fuzzy Information. Symmetry, 11(10), 1313. https://doi.org/10.3390/sym11101313

Suniantara, I. K. P., \& Suwardika, G. (2018). Penerapan Metode VIKOR pada Pengambilan Keputusan Seleksi Calon Penerima Beasiswa Bidikmisi Universitas Terbuka. Intensif, 2(1), 24. https://doi.org/10.29407/intensif.v2i1.1184 8

Sutrikanti, N., Situmorang, H., Fachrurrazi, Nurdiyanto, H., \& Mesran, M. (2018). Implementasi Pendukung Keputusan Dalam Pemilihan Calon Peserta Cerdas Cermat Tingkat SMA Menerapkan Metode VIKOR. JURIKOM (Jurnal Riset Komputer), 5(2407389X), 109-113.

Thabrani, Firmansyah, \& Sulpianti. (2019). Sistem Percepatan Proses Validasi Data dari Unified Inventory Management Berbasis Android pada PT. Telkom Witel Makassar. 689-697.

Trisnani, A. A., Anwar, D. U., Ramadhani, W., Manurung, M. M., \& Siahaan, A. P. U. (2018). Sistem Pendukung Keputusan Pemilihan Karyawan Berprestasi Menerapkan Metode Vise Kriterijumska Optimizajica I Kompromisno Resenje (VIKOR). JURIKOM (Jurnal Riset Komputer), Vol. 5 No.(2), 85-90. 
Wijaya, I., \& Mesran, M. (2019). Penerapan Metode AHP dan VIKOR Dalam Pemilihan Karyawan Berprestasi. Seminar Nasional Teknologi Komputer \& Sains (SAINTEKS) 2019, 301-309. http://prosiding.seminar-

id.com/index.php/sainteks/article/view/169

Wulan, S., Nadeak, B., Hondro, R. K., \& Waruwu, F. T. (2018). Implementasi Metode Vikor Dalam Pemilihan Kepala Sekolah Berprestasi Pada
Dinas Pendidikan Sumatera Utara. KOMIK (Konferensi Nasional Teknologi Informasi Dan Komputer), 2(1).

https://doi.org/10.30865/komik.v2i1.963 Yusnaeni, W., \& Marlina, M. (2019). Pemeringkatan Penilaian Kinerja Karyawan Melalui Metode Ahp Dan Vikor. Jurnal Pilar Nusa Mandiri, 15(2), 203-210. https://doi.org/10.33480/pilar.v15i2.715 